\title{
Electrical Resistivity Investigation for Ground Water in Parts of Pegi, Federal Capital Territory, Nigeria
}

\author{
EnahoroIfidon Asije ${ }^{1}$, Ogbonnaya Igwe ${ }^{2}$ \\ ${ }^{I}$ Department of Geology, University of Nigeria, Nsukka, Enugu State, Nigeria \\ ${ }^{2}$ Department of Geology, University of Nigeria, Nsukka, Enugu State, Nigeria
}

\begin{abstract}
Geophysical investigation involving the use of vertical electrical sounding (VES) technique was employed in the search for potential ground water target at twenty (20) locations within parts of Pegi, in Kuje Area Council of the Federal Capital Territory, Nigeria. The results of the survey indicated the presence of at least two layers of overburden (1.2-32m thick and $10 \Omega-m$ to 2,300 $\Omega-m)$ before the bedrock. The resistivity of

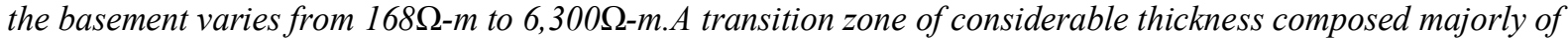
partly weathered bedrock underlies about two-third of the surveyed area. The two major aquifers in basement terrain i.e. weathered (overburden) and fractured bedrock were delineated from the geophysical investigation. Boreholes drilled within this area intercepted both the weathered and fractured bedrock aquifers. The potential for ground water in this area is good and the yield is sufficient enough to meet the demands of the clients.
\end{abstract}

Keywords: Aquifers, Resistivity, Transition zone, Vertical Electrical Sounding (VES), yield

\section{Introduction}

From its creation in 1976 and up until the early 1990's when the final relocation of the nation's capital from Lagos was effected the Federal Capital Territory, F.C.T. (Fig. 1)) has witnessed an unprecedented influx of people who have besieged the new seat of power for job opportunities both with the federal government and private establishment.

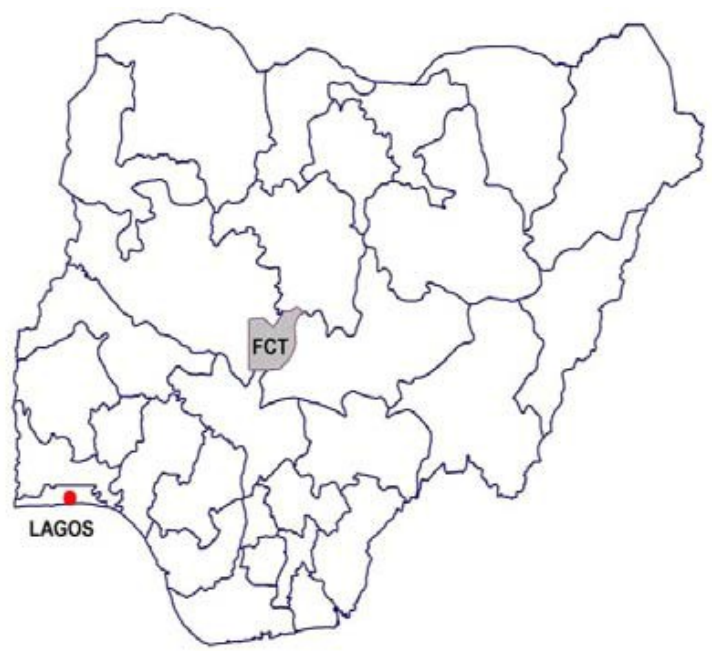

Figure 1: Map of Nigeria Showing The Location Of Lagos And The New Federal Capital Territory, (AGIS, 2006) (Culled From Jibril, 2009)

Also included in this mass movement of people are professionals and artisans who are independently offering services to the teaming population of the F.C.T. The astronomical rise in the population of the F.C.T. has led to massive shortage of basic infrastructure such as water supply. The inability of the existing Usman dam to adequately provide portable waterto meet the demand of those in the city center and environs has led the inhabitants of the FCT to source for portable drinking water at their own expense. One of such ways is through the drilling of water boreholes.In order to reduce the risk of drilling abortive wells electrical resistivity survey was therefore employed in the search for ground water in parts of Pegi, Kuje Area Council, F.C.T. (Fig. 2). 


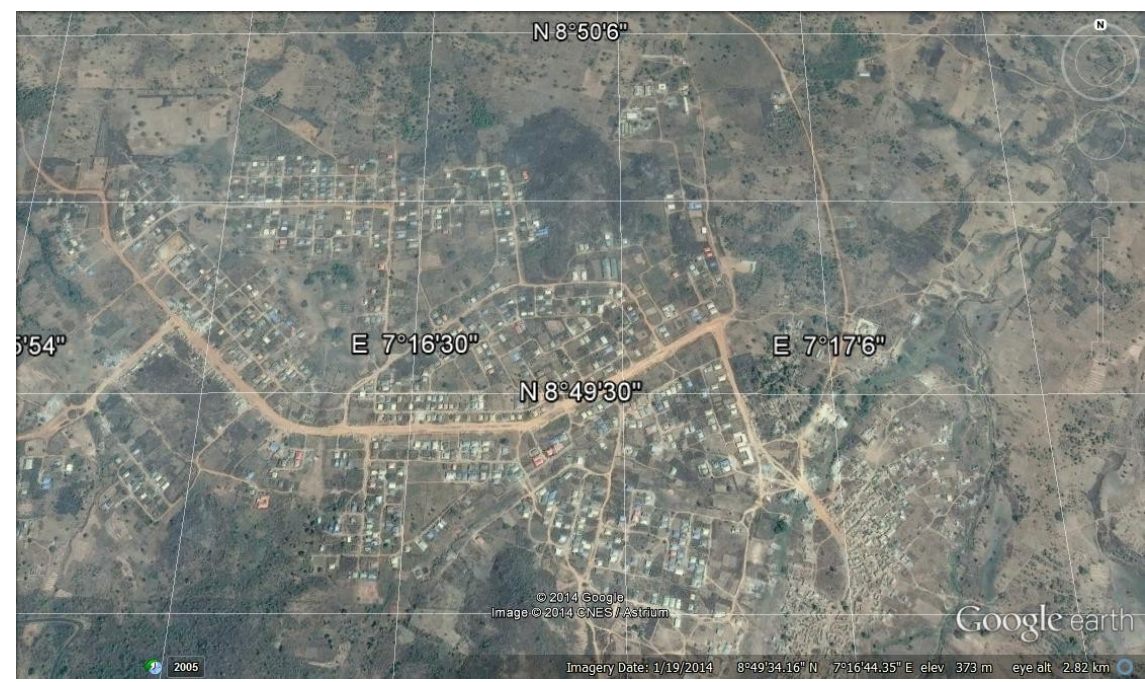

Figure2: Satellite map showing parts of Pegi (from Google Earth)

The electrical resistivity investigations discussed in this paper were carried out over a period of about two (2) years spanning between December, 2012 and May, 2014 with a total of twenty (20) survey stations (Table 1). The essence of this paper is to highlight the success of the electrical resistivity survey in delineating both weathered and fractured bedrock aquifers which have been successfully drilled and put to use in the said locality. And also make this information available to hydrogeoscientists who may want to carry out similar prospecting or drilling within the said location. It should be noted that the authors were not responsible for the drilling as they were only contracted by borehole contractors to carry out the electrical resistivity investigation. However, information about the drilling process was verbally obtained from the drillers.

\section{Geology And Hydrogeology}

The area under consideration falls within the basement complex of north-central Nigeria (Fig.3).

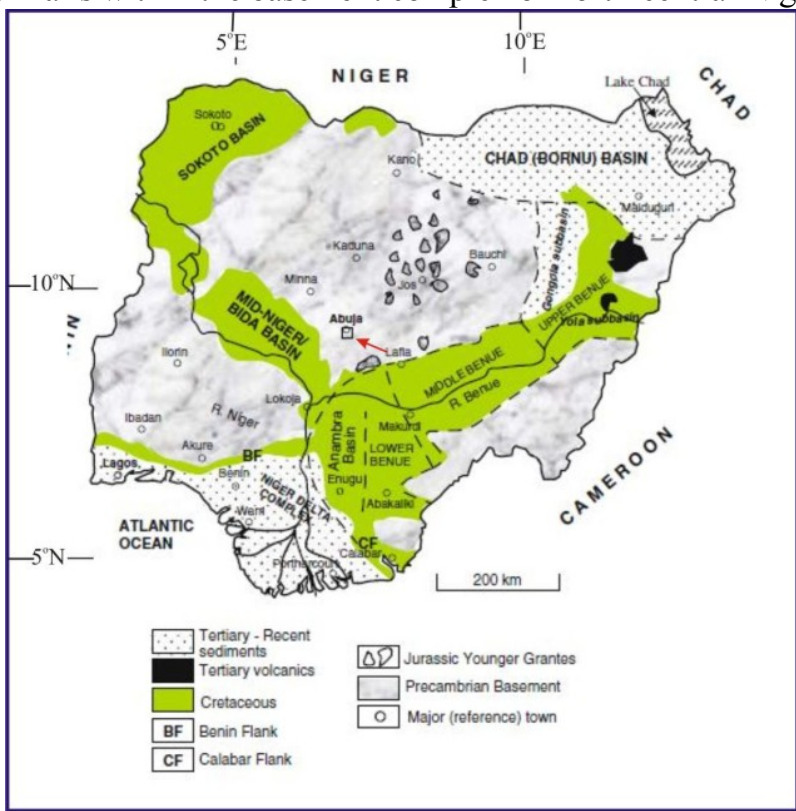

Figure 3: Geological Map of Nigeria, showing the position of Abuja (red arrow) in the Basement Complex of North central Nigeria (modified from Obaje, 2009). (culled from Omeje M. et al, 2013)

The rocks include different textures of granites, coarse to fine, consisting essentially of biotite, feldspars and quartz (Eduvie etal, 2003). In most cases the rocks have weathered into reddish micaceous sandy clay to clay materials capped by laterites (Offodile 1992). The main sources of water in basement complex are the weathered/transition zone and fractured basement rocks. 


\section{Materials And Method}

The popular VERTICAL ELECTRICAL SOUNDING (VES) of electrical resistivity method was employed. Basically, the method was designed to detect the physio-structural characteristics of basement rocks such as variation in conductivity and thereby determine the depth of occurrence of productive aquifers. The survey involved the selection of 20 geo-stations and probing points. Schlumberger array was employed using Allied Ohmega Resistivity Meter. Coordinates of VES points were obtained using Garmin's Geographical Positioning System (GPS) Personal Navigation unit.The field data obtained wereinterpreted using IPI2Win Resistivity Sounding Interpretation Software (1990-2008). Surfer 10 from Golden Software, Inc. was used to enhance the presentation of the interpreted data.

\section{Results And Discussion}

The data set analysis of all the sounded points indicated at least two layers of regolith or overburden before the bedrock. Typical curve types analysed from the field data are KH, $\mathrm{H}$ and HQ. The KHand H-type curve accounted for $85 \%$ of the total curve types (Table 1 and Fig.4a-c).

Table 1: Summary of VES Interpretation

\begin{tabular}{|c|c|c|c|c|c|c|c|c|c|c|c|c|c|}
\hline \multirow[b]{2}{*}{ Date } & \multirow[b]{2}{*}{$\begin{array}{l}\text { VES } \\
\text { No. }\end{array}$} & \multicolumn{2}{|c|}{ UTM } & \multicolumn{4}{|c|}{ Layer resistivity } & \multicolumn{3}{|c|}{ Depth } & \multirow[t]{2}{*}{ Inferred Lithology } & \multirow[t]{2}{*}{$\begin{array}{l}\text { Curve } \\
\text { Type }\end{array}$} & \multirow[t]{2}{*}{ Overburden thickness } \\
\hline & & Easting & Northing & pl & $\rho 2$ & p3 & ot & dl & $\mathrm{d} 2$ & d3 & & & \\
\hline 241212 & 1 & 311186 & 975861 & 1424 & 151 & 359 & . & 1.08 & 11.7 & . & hardpan, sandy clay and fractured basement & $\mathrm{KH}$ & 11.7 \\
\hline 120113 & 2 & 310506 & 976359 & 822 & 172 & 1271 & . & 0.6 & 10.1 & & laterite, sandy clay, fractured basement & $\mathrm{H}$ & 10.1 \\
\hline 40213 & 3 & 310402 & 976351 & 627 & 220 & 81 & 719 & 0.5 & 7.5 & 14 & clayey sand, sandy clay, fractured basement & $\mathrm{H}$ & 13.9 \\
\hline 603113 & 4 & 310567 & 976100 & 252 & 102 & 39 & 2214 & 1.2 & 7.2 & 14 & sandy clay, clay, fractured basement & $\mathrm{H}$ & 13.6 \\
\hline 1103113 & 5 & 310354 & 976305 & 531 & 132 & 718 & 168 & 1.2 & 3.4 & 14 & sandy clay, clayey sand, fractured basement & HQ & 3.5 \\
\hline 2103113 & 6 & 310520 & 976355 & 368 & 109 & 33 & 3366 & 1.7 & 6.2 & 32 & sandy clay, clay, fairly fractured basement & $\mathrm{H}$ & 32.3 \\
\hline 110413 & 7 & 310617 & 976009 & 202 & 415 & 21 & 245 & 0.9 & 1.7 & 5.2 & sandy clay, clayey sand, clay, fractured basement & $\mathrm{KH}$ & 5.2 \\
\hline 170613 & 8 & 310628 & 976026 & 130 & 518 & 9.1 & 1248 & 1.2 & 2.9 & 7.5 & sandy clay, clayey sand, clay, fractured basement & $\mathrm{KH}$ & 7.5 \\
\hline 170813 & 9 & 309742 & 976427 & 107 & 462 & 160 & 6433 & 0.5 & 10.7 & 21 & Sandy clay, clayey sand, fractured basement & $\mathrm{KH}$ & 20.7 \\
\hline 260813 & 10 & 310672 & 976283 & 57 & 1583 & 28 & 706 & 0.5 & 1.1 & 5 & clay, laterite, fractured basement & $\mathrm{KH}$ & 5 \\
\hline 021013 & 11 & 310767 & 975697 & 350 & 74 & 2150 & 1850 & 0.5 & 0.6 & 5.5 & sandy clay, clay, fractured basement & HQ & 1.2 \\
\hline 150214 & 1.2 & 310527 & 976467 & 225 & 1025 & . & . & 14.2 & . & . & sandy clay, fractured basement & A & 14.2 \\
\hline 1503114 & 13 & 310229 & 976449 & 1517 & 168 & 93 & 1286 & 0.7 & 2.5 & 17 & laterite, sandy clay, fractured basement & $\mathrm{H}$ & 17.3 \\
\hline 190314 & 14 & 310250 & 975865 & 706 & 2207 & 206 & 1682 & 0.5 & 1 & 14 & clayey sand, laterite, sandy clay, fractured basement & $\mathrm{KH}$ & 14.2 \\
\hline 2703114 & 15 & 309972 & 975885 & 2348 & 10 & 1534 & . & 0.9 & 7.3 & . & laterite, clay, fractured basement & $\mathrm{H}$ & 7.3 \\
\hline 08041.14 & 16 & 309998 & 975991 & 328 & 266 & 1426 & . & 0.5 & 12.4 & . & sandy clay, fractured basement & $\mathrm{H}$ & 12.4 \\
\hline 08041.14 & 17 & 310428 & 976461 & 453 & 266 & 16 & 1544 & 0.7 & 5.2 & 12 & clayey sand, clay, fractured basement & $\mathrm{KH}$ & 12.4 \\
\hline 190414 & 18 & 309907 & 975945 & 275 & 409 & 124 & 907 & 0.5 & 3.6 & 9.6 & sandy clay, clayey sand, fractured basement & $\mathrm{KH}$ & 9.6 \\
\hline 19041.4 & 19 & 309824 & 976028 & 116 & 327 & 192 & 725 & 0.5 & 1.6 & 5.2 & sandy clay, fractured basement & $\mathrm{KH}$ & 5.2 \\
\hline 12051.14 & 20 & 309964 & 975920 & 66 & 229 & 51 & 399 & 0.5 & 4 & 9 & sandy clay, clay, fractured basement & $\mathrm{KH}$ & 13.6 \\
\hline
\end{tabular}




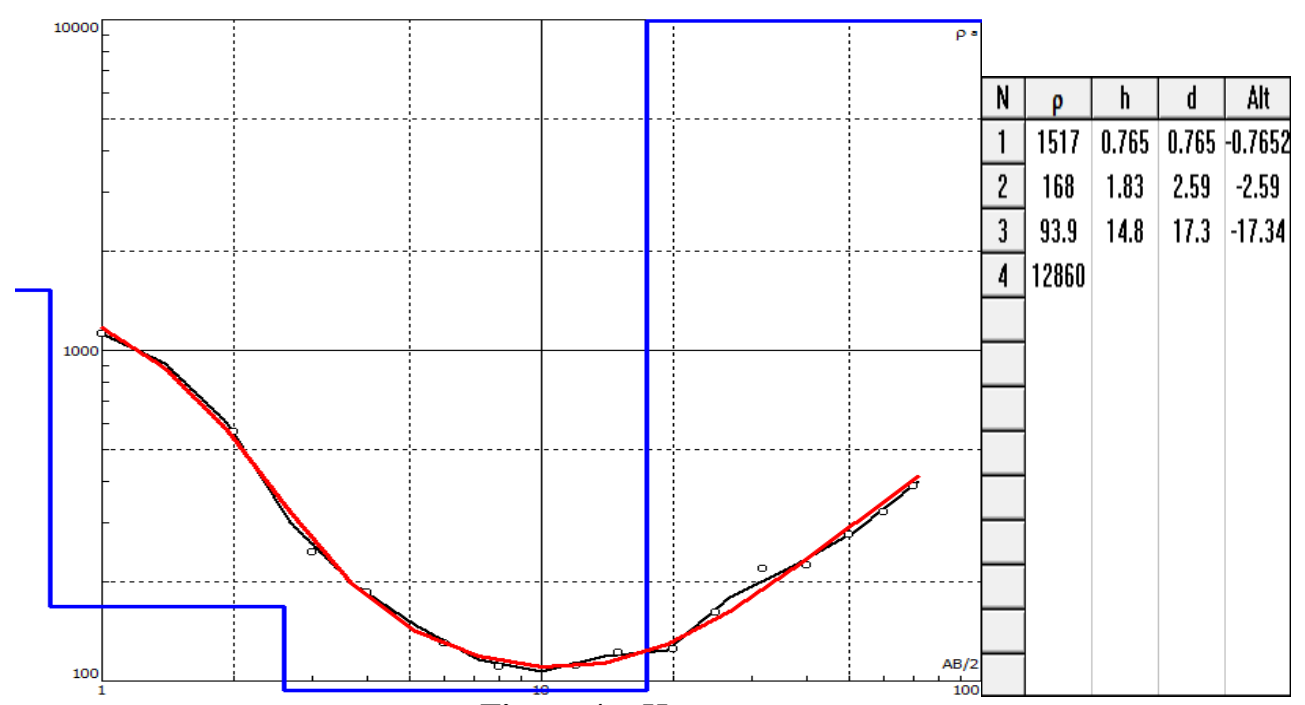

Figure 4a: H-type curve

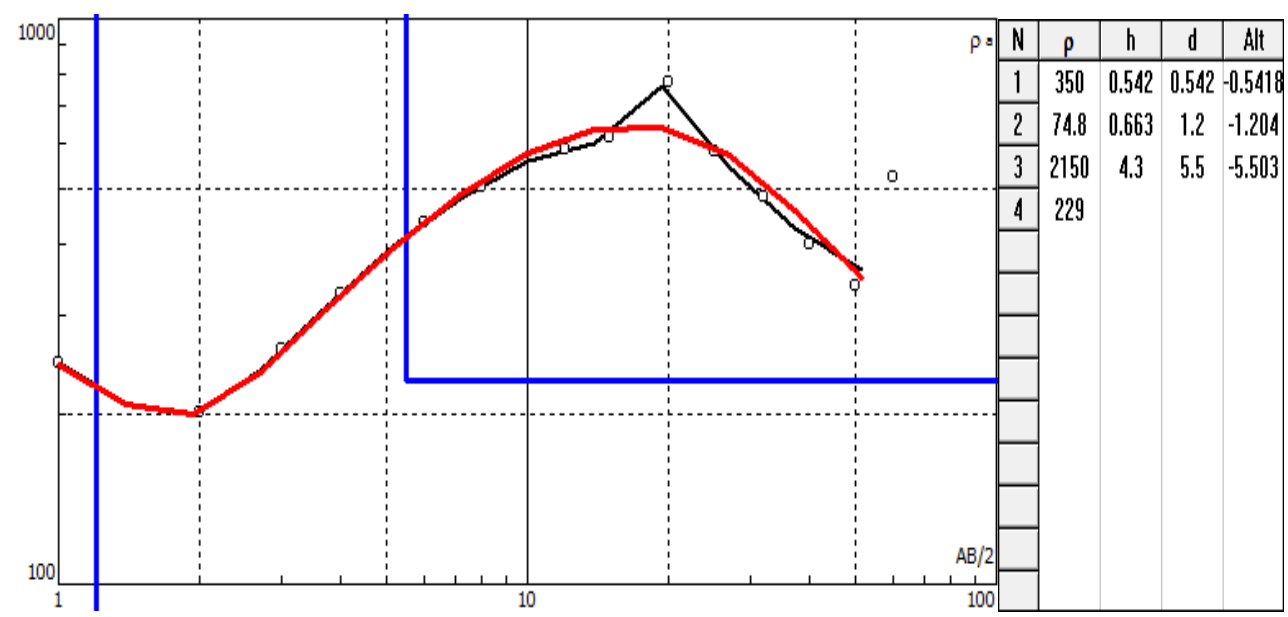

Figure 4b: HQ-type curve

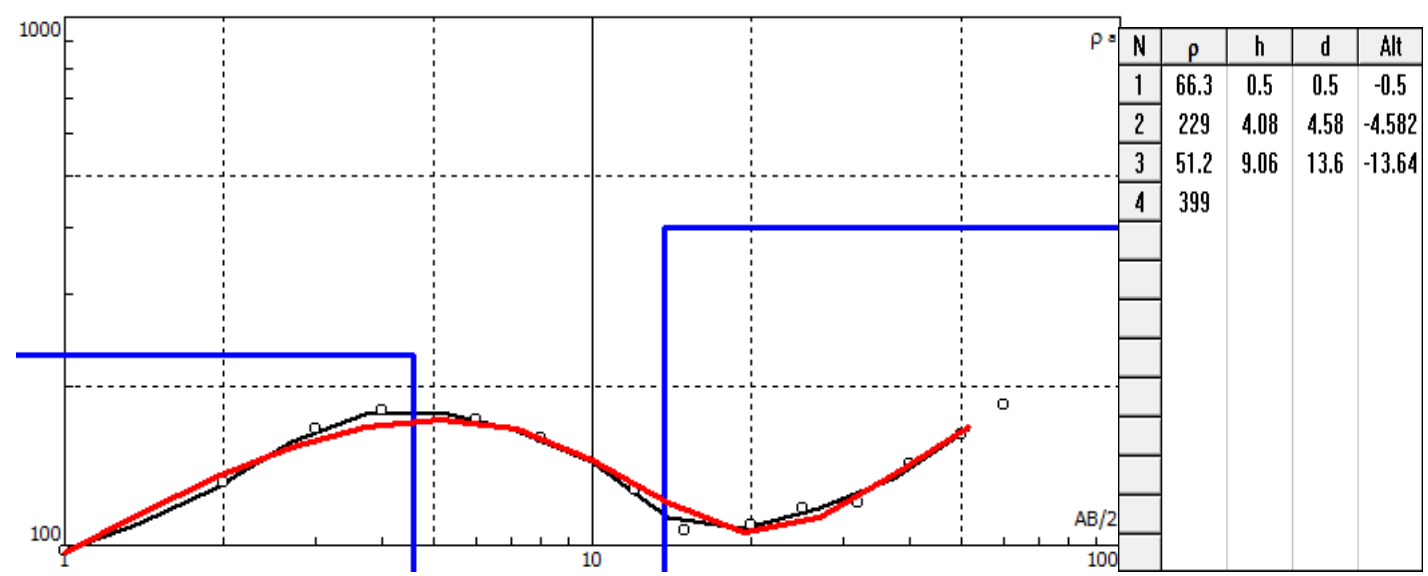

Figure 4c: KH-type curve

\subsection{ISO-Pach And Iso-Resistivity Map Of The Overburden}

Overburden thickness viz-a-viz depth to bedrock varies from 1.2 meters at the shallowest to about 32 meters Fig.5).Overburden is thickest at the north-central end of the area marked " $T$ " and shallowest at the south- 
eastern end of the area marked " $\mathrm{S}$ " where the overburden thickness is almost negligible.

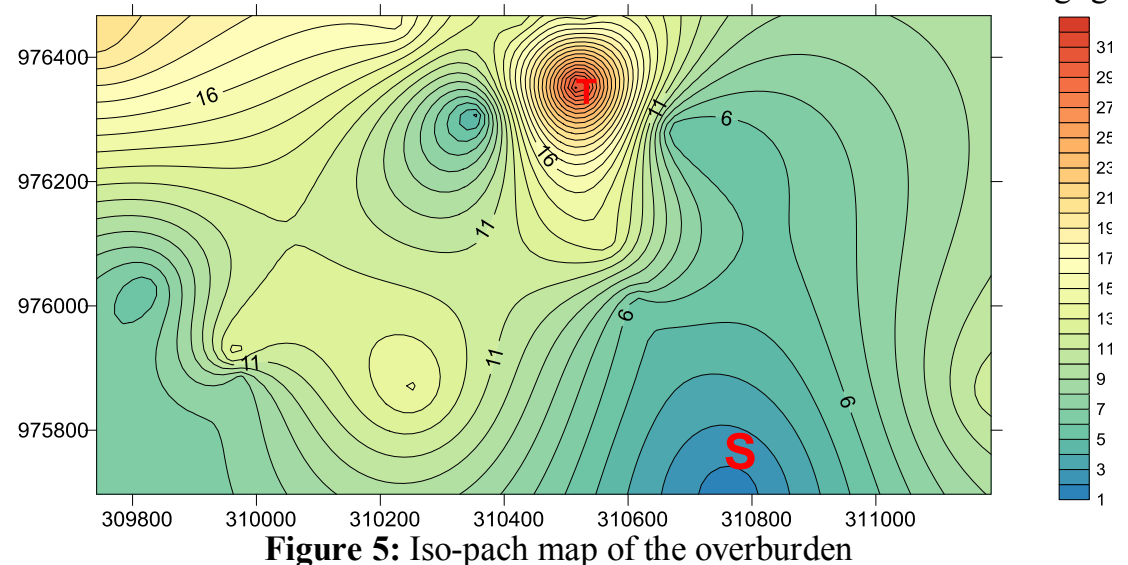

Average overburden thickness around the area is about 10 meters. The area marked " $T$ " also infer a depression or trough within the bedrock configuration with the properties of a reservoir capable of storing underground water. And as such the thick overburden at this area would act as good aquifer for underground water development.

Resistivity of the overburden varies from as low as $10 \Omega-\mathrm{m}$ at the north-central part of the area to as

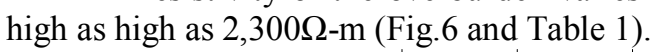

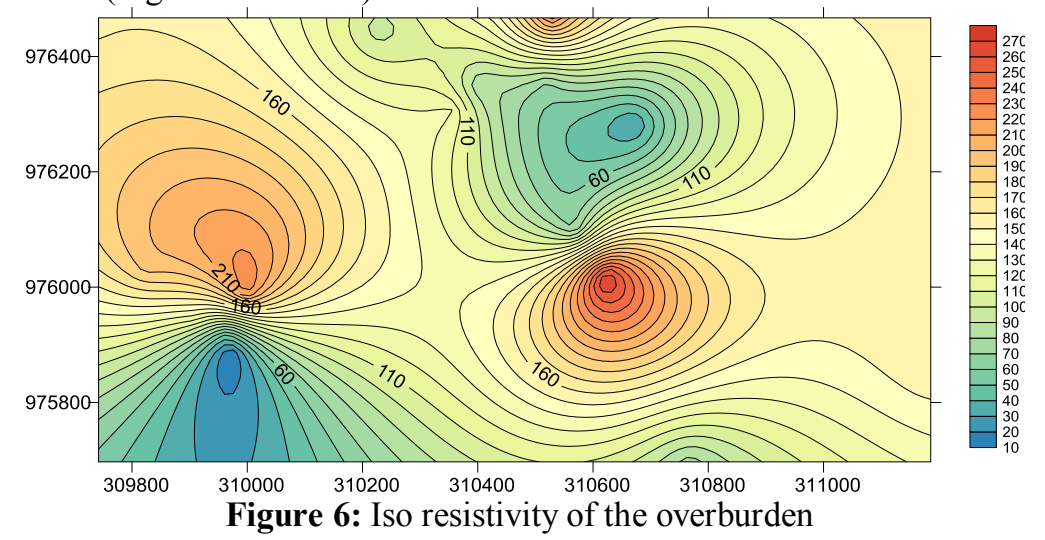

Inferred lithologicunits of the overburden delineated on the basis of resistivity values obtained are laterite, hardpan, sandy clay, clay and clayey sand (Table 1). Wherever the laterite and hardpan were delineated at any given VES point they usually appear within the first two layers i.e. from the surface.

\subsection{ISO-Resistivity Of The Bedrock}

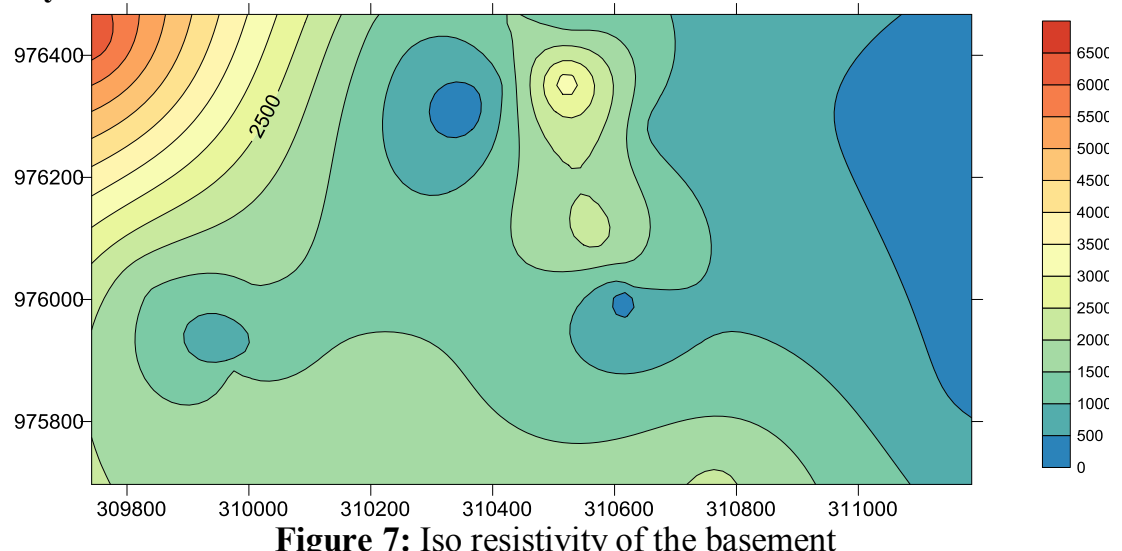

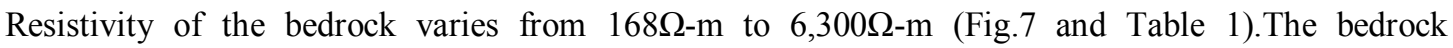
resistivity depicts a geological formation with well-developed secondary fractures i.e. bedrock aquifers, across the entire surveyed points. Depth to this zone varies from as low as 2 meters to as high as 32 meters (Fig.5 and 
Table 1). A transition zone composed of partly weathered bedrocks between the overburden and bedrock was inferred from the iso-resistivity map on areas with bedrock resistivity of less than $1500 \Omega-\mathrm{m}$. This zone appears to cover more than two-third of the entire survey area.And as such, no distinct contact between the overburden and bedrock appear to exist within such locations.It was therefore recommended that wells to be drilled within this zone should be cased to the bottom and well gravel-packed to forestall future collapse or caving.

Hard, competent and fractured bedrock is expected to be encountered at the extreme north-western part of the area (Fig.7).

The bedrock therefore has good potential for underground water development. Information obtained from the drilling contractor corroborated the findings above. All the wells drilled have since been commissioned and put to use by the individual clients. Yields were satisfactory.

\section{Conclusion}

Electrical Resistivity investigation for ground water was carried out at some parts of Pegi in Kuje Area Council of the F.C.T. Nigeria.The method proved successful in delineating both weathered and fractured bedrock in relation to aquifer potential of the area and guided the location of drill points for productive water boreholes.

It was however observed that where ever the overburden had a considerable thickness i.e. transition zone, the contact between the overburden and the bedrock was difficult to delineate.

Hydrogeoscientists who may want to carry out similar prospecting or drilling program within the said locality should put this into consideration while making recommendations for drilling by ensuring that provision is made for down-to-bottom casing and gravel-packing to forestall future collapse or caving of the drilled well.

\section{References}

[1]. Ibrahim UsmanJibril (2009). Squatter Resettlement/ Relocation Programme in Abuja, Nigeria and theIssue of Land Title Security.FIG Working Week 2009, Surveyors Key Role in Accelerated Development Eilat, Israel, 3-8 May 2009

[2]. 2013 Google Earth Inc.

[3]. Omeje M., Husin W., Noorddin I., Oha I. A., Onwuka O.S, Ugwuoke P. E. and Meludu (2013). Geoelectrical investigation of aquifer problems in Gosa area of Abuja, North Central, Nigeria.Int. J. Phys. Sci. Vol. 8(13), pp. 549-559

[4]. [M.O. Eduvie, T. Olabode and O.O. Yaya, Nigeria (2003). Assessment of groundwater potentials of Abuja environs. Towards the Millennium Development Goals, 29th WEDC International Conference Abuja, Nigeria.pp 183-187

[5]. M.E. Offodile, An Approach to Groundwater Study and Development in Nigeria(Mecon Services Ltd., Jos,1992) 